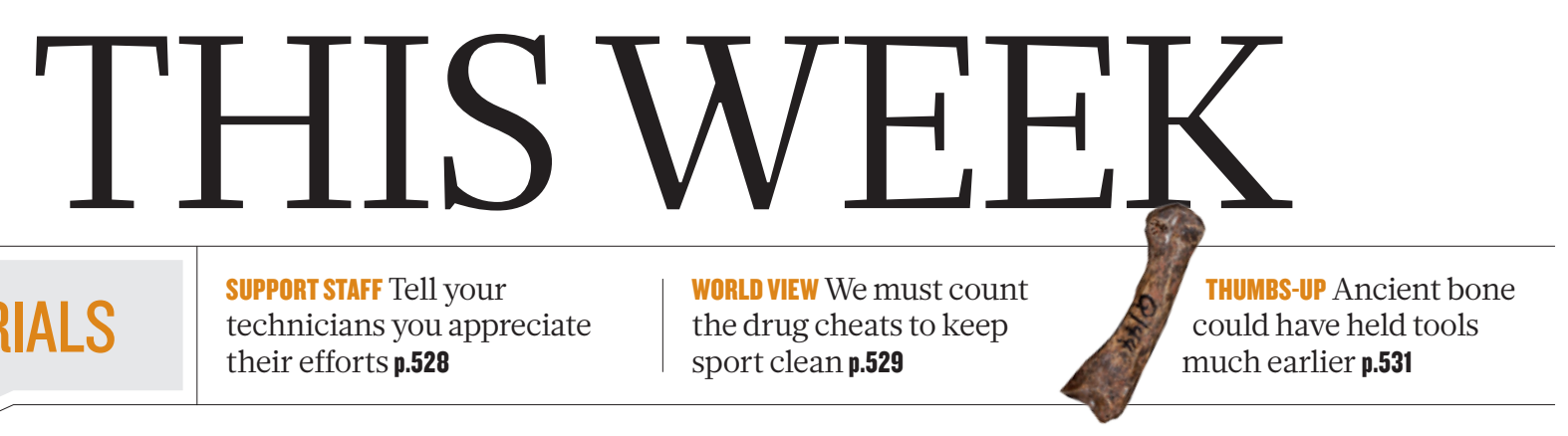

SUPPORT STAFF Tell your their efforts p.528

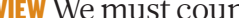
keep EDITORIALS

\title{
Human history defies easy stories
}

\author{
The discovery of part of a 55,000-year-old human skull in Israel will help to answer some \\ questions about our species' evolution - but it shows that the tale is complicated.
}

W hen modern humans spread out of Africa and across Eurasia 60,000-40,000 years ago, they replaced all other members of the human family, and laid the foundations for the modern world. Who were these ancestors? They left few fossils, and fewer answers.

A new piece of the puzzle is reported this week on Nature's website: a partial skull found in Manot Cave in northern Israel that has been dated to around 55,000 years ago (I. Hershkovitz et al. Nature http:// dx.doi.org/10.1038/nature14134 (2015) and page 541). The skull, which has a distinctive 'bun'-shaped occipital bone (the lower-back region), resembles those of modern humans found in Europe, dating to the Upper Palaeolithic starting around 50,000 years ago.

Where does the find fit in? Beware simple answers, and, indeed, simple questions. There is a temptation when discussing human evolution to reconstruct it as a narrative, in which successive species evolved to be more like us, and the more like us they became, the more likely they were to migrate to other parts of the world and replace pre-existing forms.

There are at least four things wrong with this. The first is its rather imperialist framing, in which evolution and replacement can be justified after the fact as a kind of manifest destiny.

The second is that it dismisses any extinct species as inferior and therefore of secondary importance.

The third is that it assumes the existence of an arrow of progress, in which species always evolve towards ourselves, a mistaken view that is too welcoming of spurious conceits such as 'missing links', and unwilling to countenance odd side branches such as Homo floresiensis, the peculiar, dwarf hominin (member of the human family) that lived in Indonesia until relatively recent times (see nature.com/hobbit10).

The fourth, and arguably the most important, is that it misrepresents the extreme fragmentation of the fossil record, something that Charles Darwin recognized, with his usual percipience, as a 'difficulty' with his theory of evolution by natural selection. Darwin was (as usual) selling himself short. That evolution has happened is no longer in doubt: the shared chemistry and structure of all life, from the meanest microbe to the furriest feline, would be testament to that, even had no fossils ever been found.

Fossils offer more than concrete proof that evolution happened. They reveal a wealth of organic forms that no longer exist. The only species of hominin alive today, as far as we know, is our own, Homo sapiens. But this sole estate hides a large number of extinct forms, each of which contributed to Earth's ecology in its own particular way. If the present epoch is unusual, it is in the presence of just one species of hominin. A mere 50,000 years ago, there were at least four different species. There are very likely to have been more.

Homo sapiens first appears in the fossil record around 200,000 years ago in Ethiopia, albeit in a distinctly archaic form. The earliest fossil is not the same as the earliest member of a species - H. sapiens is probably much older than this. Archaic forms of our species outside
Africa first appear around 90,000 years ago, in the Levant. Another 45,000 years or so were to pass before our species made it to southeastern Europe, where it appeared amid a spectacular flourish of technology and what we would instantly recognize as art.

What happened between 90,000 and 45,000 years ago, a period ten times the length of recorded history? Only the fossils can tell us, and they are few. It seems that the earliest modern humans got to
"What happened between 90,000 and 45,000 years ago? Only the fossils can tells us, and they are few." the Levant and no farther. Mount Carmel in Israel hosts caves, such as Qafzeh and Skhul, where H. sapiens remains appear in levels older than those occupied by Neanderthals, Homo neanderthalensis. The replacement of our own species by Neanderthals seems to be an affront to our prejudices. So how did humans eventually make it to Europe?

The partial $H$. sapiens skull from Manot Cave goes some way towards providing an answer, as well as hinting at how complicated our early history might have been. It looks much more modern than skulls from Qafzeh and Skhul. It is also much younger, suggesting that the hominin was closer, genetically and evolutionarily, to the earliest known European representatives of our species. This skull, the simple answer would suggest, represents modern humans poised to expand out of Africa and colonize the rest of the world.

Here comes the 'but'. Our modern genomes contain Neanderthal DNA. At some point, our ancestors bred with Neanderthals before they became extinct. Does the Manot skull represent that moment? We simply do not know. Welcome, Manot skull, to messy reality.

\section{Senate vs science}

\section{A few Republicans agreeing with basic climate research is not an environmental victory.}

$\mathrm{U}$ S President Barack Obama challenged his conservative climate critics in the annual State of the Union address to Congress on 20 January, arguing that they cannot shy away from modern climate science. A day later, pushed to take a position, 15 Republicans voted in favour of an amendment affirming the idea that humans have a role in climate change. Five went a step further, voting for a Democratic amendment stating that human activity "significantly contributes to climate change". And this is progress?

Although both amendments attracted a majority of the US Senate, neither achieved the 60 -vote threshold required for approval. These votes are of course purely symbolic, but political types are already busy 